Spring 2004

\title{
So Much Depends: Printed Matter, Dying Words, and the Entropic Poem
}

Clark Lunberry

University of North Florida, clark.lunberry@unf.edu

Follow this and additional works at: https://digitalcommons.unf.edu/aeng_facpub

Part of the English Language and Literature Commons

\section{Recommended Citation}

Lunberry, Clark, "So Much Depends: Printed Matter, Dying Words, and the Entropic Poem" (2004). English Faculty Publications. 3.

https://digitalcommons.unf.edu/aeng_facpub/3

This Article is brought to you for free and open access by the Department of English at UNF Digital Commons. It has been accepted for inclusion in English Faculty Publications by an authorized administrator of UNF Digital Commons. For more information, please contact Digital Projects.

(C) Spring 2004 All Rights Reserved

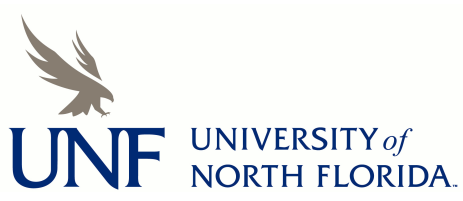




\title{
So Much Depends: Printed Matter, Dying Words, and the Entropic Poem
}

\author{
Clark Lunberry
}

The words will have to be rebricked up, the

-what? What am I coming to

pouring down?

—William Carlos Williams, Paterson

Growing up in Rutherford, New Jersey, in the 1940s, Robert Smithson would periodically visit his pediatrician, William Carlos Williams, who had his home and medical practice across town at Nine Ridge Road. There were, no doubt, the routine checkups, the childhood ailments and inoculations, the doctor looking into the mouth, the ears, the eyes of the little boy. Many years later, in 1958 - Williams by then retired and Smithson a young artistthey would once again meet informally at the poet's home. ${ }^{1}$ Nearing the end of his long life, Williams-no longer practicing medicine-was nonetheless still very much practicing poetry, laboring away at his never-ending Paterson, the epic, multivolume poem of the nearby city begun decades earlier. The young Smithson, on the other hand, was at the beginning of what would be his unforeseeably short life. From this visit, Smithson reported (as if he were the one now examining the patient) that Williams, having recently suffered several strokes, "was in pretty bad shape at that time, he was kind

I could never thank Herbert Blau enough for all of his invaluable guidance over the years in helping me to see-however ghostly or ghosted—something of what I'm trying to say in this essay. Also, my many talks with Daniel Listoe while working on this piece proved incredibly useful and, in the end, absolutely necessary.

1. Smithson visited Williams that day with the poet Irving Layton to discuss an introduction that Williams had agreed to write for a collection of Layton's poems.

Critical Inquiry 30 (Spring 2004)

(C) 2004 by The University of Chicago. 0093-1896/04/3003-0006 $\$ 10.00$. All rights reserved. 


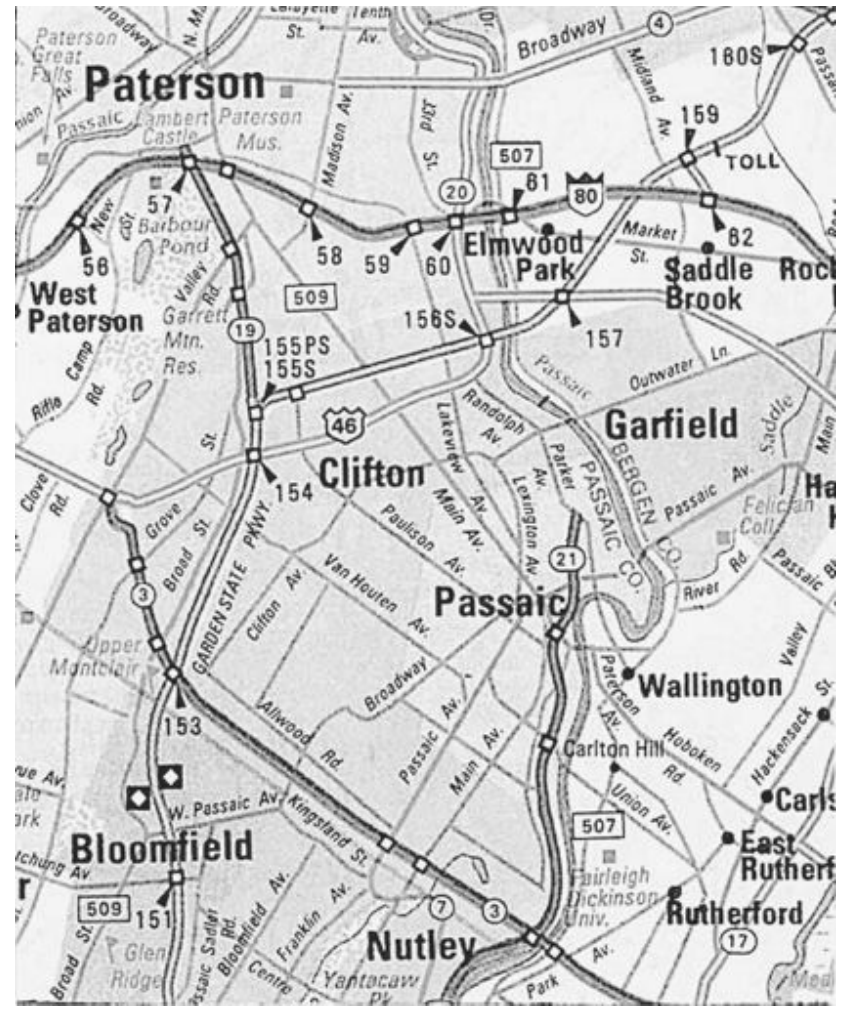

FIG URE 1.

of palsied." 2 On that day, however, Williams was to recall with pleasure the Smithson family, delighted to see that the little boy he remembered had come by to visit, that he had returned as an artist (fig. 1).

In a 1972 interview, a year before his accidental death in an airplane crash at the site of a final earthwork in Texas (and nine years after Williams's death from a final stroke), Smithson elaborated upon his relationship with Williams. Here, he provocatively described parts of Williams's Paterson as

2. Robert Smithson, "Interview with Robert Smithson for the Archives of American Art/ Smithsonian Institution," interview by Paul Cummings, Robert Smithson: The Collected Writings, ed. Jack Flam (Berkeley, 1996), p. 284.

CLARK LUNBERRY is an assistant professor in the department of English at the University of North Florida. He has published several articles on the interrelations of the arts and literature as well as a book of poems, StonePoems (1999). He is now completing a book manuscript on silence/absence in the arts. 
"proto-conceptual art," while recalling his own connections to the region, his boyhood explorations of abandoned mining sites: "I guess the Paterson area is where I had a lot of my contact with quarries and I think that is somewhat embedded in my psyche."3 Smithson showed a real interest in Paterson's collaged conjoining of poetry and prose, and he later went on to claim an even more direct link with Williams, stating that his own essay "A Tour of the Monuments of Passaic, New Jersey" - a photomontage of text and image, of site and sightlessness - could be conceived of "as a kind of appendix to ... Paterson, " while updating or upending the image of the area as something that "comes out of that kind of New Jersey ambiance where everything is chewed up. . . . a kind of destroyed . . . derelict California." 4

Begun in the 1920 s as another of his short poems about a particular place, ${ }^{5}$ Paterson was to transform itself (again and again) in the decades that followed into an ever-expanding poem that Williams was never quite able to complete. The poem was built upon the idea "that a man in himself is a city, beginning, seeking, achieving and concluding his life in ways which the various aspects of a city may embody." As noted in his essay "The Importance of Place," the city of Paterson permitted him to "abjure the unknowable and begin within a certain tacitly limited field of human possibility ..., located outside the mind ..., a place on which to rest the emotions." From such a predetermined vantage, as he writes in Paterson's openinglines, he was then "to make a start, / out of particulars / and make them general, rolling / up the sum, by defective means-" $(P, \mathrm{p} .3)$. Oriented around the Passaic River, with the Great Falls as the poem's "central figure," Paterson presents the river's rushing waters as a concrete image upon which Williams endeavored to structure and sustain his work. Williams wrote, "From the beginning I decided there would be four books following the course of the river whose life seemed more and more to resemble my own life as I more and more thought of it: the river above the Falls, the catastrophe of the Falls itself, the river below the Falls and the entrance at the end into the great sea" ( $P$, p. xiii).

Yet Williams must have nonetheless wondered just how solid and stead-

3. Ibid., p. 285.

4. Smithson, "Conversation in Salt Lake City," interview by Gianni Pettena, Robert Smithson, p. 298.

5. In 1927 Williams published the two-page poem "Paterson." Within it, one can partially see, as by preliminary sketch, the outlines of the larger poem to come. See William Carlos Williams, "Paterson," The Dial (1927): 263-66.

6. Williams, Paterson (New York, 1992), p. 253; hereafter abbreviated $P$.

7. Williams, “The Importance of Place," The Embodiment of Knowledge, ed. Ron Loewinsohn (New York, 1974), pp. 132-33. 
fast a relentlessly plunging waterfall could ever be, how controllable an image its torrential flow. For many of the poem's convolutions quickly arose as the words of the poem, and the "particulars" of the place, kept coming, "pouring down," like the powerful falls at its center. Long before Smithson's own appending to Paterson, Williams was himself forever finding fresh material to graft upon the old, uncovering new dimensions to the poem's rich terrain. First conceived of as four books, then five, then six, the unfinishable work was about a place that was to remain uncontainable, a city in its indeterminate unfoldings, forever eluding its own conclusion. As a poem that began by being patterned upon a river's life that resembled the poet's own, such mirroring resemblance must have come to seem increasingly baffling and strange, no longer offering consolations of the knowable, the locatable.

In the poem's opening pages, Williams speaks of language itself as a slippery medium or untrustworthy tool, addressing directly the dilemma of applying words to ideas, thought to things. At first, he appears to partially acknowledge the difficulty of his own stated task of "locating" and knowing the city, as he makes specific reference to the limits of language and just what carefully crafted words and sentences might finally (or not) be able to convey. He speaks again and again of language's intractability, its resistance to retention, and- "by defective means" - the restraints of our own sustainable awareness, "since we know nothing, pure / and simple, beyond / our own complexities” ( $P$, p. 3). But looked at more closely, especially at the poem's beginning, the restraints and limits spoken of and described are almost always directed towards "they" and "them," others for whom the language is scattered and unavailing:

The language, the language

fails them

They do not know the words

or have not

the courage to use them

They may look at the torrent in

their minds

and it is foreign to them.

the language!

- the language

is divorced from their minds

$$
\text { [P, pp. 11-12] }
$$

The poet, however, carefully listening and looking, is presented in Paterson's opening pages as being better positioned-perhaps like a trained 
doctor diagnosing disease-to uncover the subterranean patterns of the place, to intercept the otherwise indiscernible flows and frequencies coming from the city's center. "Locked in the mind," away from others, the "rigor of beauty" would nonetheless be revealed to the one who persisted in the listening and the looking $(P, \mathrm{p} .3)$-the falls themselves, the rushing waters, would be "combed into straight lines / from that rafter of a rock's / lip" ( $P$, p. 7). Time would finally tell; patience would provide the poet with the more vivid perspective, a steadied seeing onto the site.

Yet in its obsessive hold upon Williams the poem from its very inception taunted, challenged, and exceeded perception: "That God damned and I mean God damned poem Paterson," Williams exclaimed in 1943. "I'm burned up to do it but don't quite know how. I write and destroy, write and destroy" - as he tried year after year to nonetheless find a writable structure to accommodate the entangling, transforming reality, the work again and again getting "side-tracked ..., turn[ing] into something else."

By choosing, however, the Passaic Falls as the central feature of his poem, its turbulent waters as both the "lucky burden of what I wanted to say" and the acknowledged site of "catastrophe" ( $P$, p. xiii), Williams instinctively knew - in spite of his best and most audacious of intentions- the impossibility of what he was attempting to achieve. He understood that the river was not going to divulge some translatable secret, some formable story: "aware of the stream / that has no language ... the violent torrent rolling over us" ( $P$, pp. 23-24). As a younger man driving in his car (and as exemplified in "Spring and All"), ${ }^{9}$ Williams had before fashioned a form of seeing (in motion) that was tethered lightly to the fleeting and isolated glance-the nouns as progressive verbs, images cataracting towards their own disappearance. In this later work, though, Williams sought something larger and more sustaining, a form of writing that, however defectively, might adequately accommodate the power of the place, its brute force. The moving glance had given way to the protracted gaze, for a stilled presence more fixedly pictured.

8. Quoted in Christopher MacGowan, preface to $P$, pp. xi, xii; hereafter abbreviated "P." Williams wrote to a friend in 1944 (with nearly twenty more years of working on the poem ahead of him) that Paterson was "near finished," and then nine months later, it was "nearing completion," while finally, some months later, the poet wished of the poem that he could "slash it unmercifully," even suggesting that it be destroyed entirely (quoted in "P," p. xi).

9. Indeed, Williams's automobile was for the young doctor a kind of time machine, stopping and starting, propelling him down the street, with the momentary view now gliding by through windows - seen through a new awareness of temporality and transformation "the delineation of the cresence and ebb ... sliding into nothing" (Williams, "Spring and All," Imaginations [New York, 1971], p. 135; hereafter abbreviated "SA"). He sees the sights and knows that he has seen them just at the moment of their loss or, rather, has seen them as the moment of their loss, at the very vanishing point of vision's fleeting contact with the world. "It is," Williams writes, "only in isolate flecks that / something / is given off / No one / to witness / and adjust, no one to drive the car" (“SA," p. 133). 
The language . words

without style! whose scholars (there are none)

or dangling, about whom

the water weaves its strands encasing them

in a sort of thick lacquer, lodged

under its flow

$$
\text { Caught (in mind) }
$$

beside the water he looks down, listens!

But discovers, still, no syllable in the confused

uproar: missing the sense (though he tries)

untaught but listening, shakes with the intensity

of his listening

Only the thought of the stream comforts him,

its terrifying plunge

$$
\text { [P, pp. 81-82] }
$$

In a 1970 interview, Smithson talks about Paterson, the city and the poem, and specifically the Passaic Falls at the city's center. In describing his own "flow pieces" - the most well known being Asphalt Rundown (1969), in a quarry in Italy, where a dump truck poured a full load of hot asphalt down a deeply eroded hill-there is in relation to Williams a kind of ironic mirroring of creative intent, a reversal of viewable fortunes (fig. 2). For Smithson's flow of asphalt finally represents, of course, hardly any kind of flow at all, as it thickly spills down the steep incline, an "alluvial action, fluvial massing ... that moves from a central point and fans apart, ... then it suddenly is arrested, and once again, the flow is caught." Filling the hill's deep crevices, following the cracks of its heavily weathered crust, "the piece is at once solidly there, but it's subject to the elements.... The first incident [of pouring] is like a dot on a line, and in a sense this is like a mark on a surface, and it's a fall, a slow fall. You might say that there's also a correlation to Williams. ... the associations you could have with the falls from Paterson." 10

But what might these correlations and associations be? If the Passaic Falls in Paterson was the desired site for Williams of an extractable language, the torrent of water a possible source for the telling of the story of his "selected" city ( $P$, p. xiii), Smithson's gluttonous flow of hot asphalt down a hill, cooling and then coagulating into rigid form, seems instead a kind of crude occlusion of the fluid, a solidified barrier to extracting anything at all. The asphalt itself, like a thick, granular ink, may have begun like a writerly "mark 


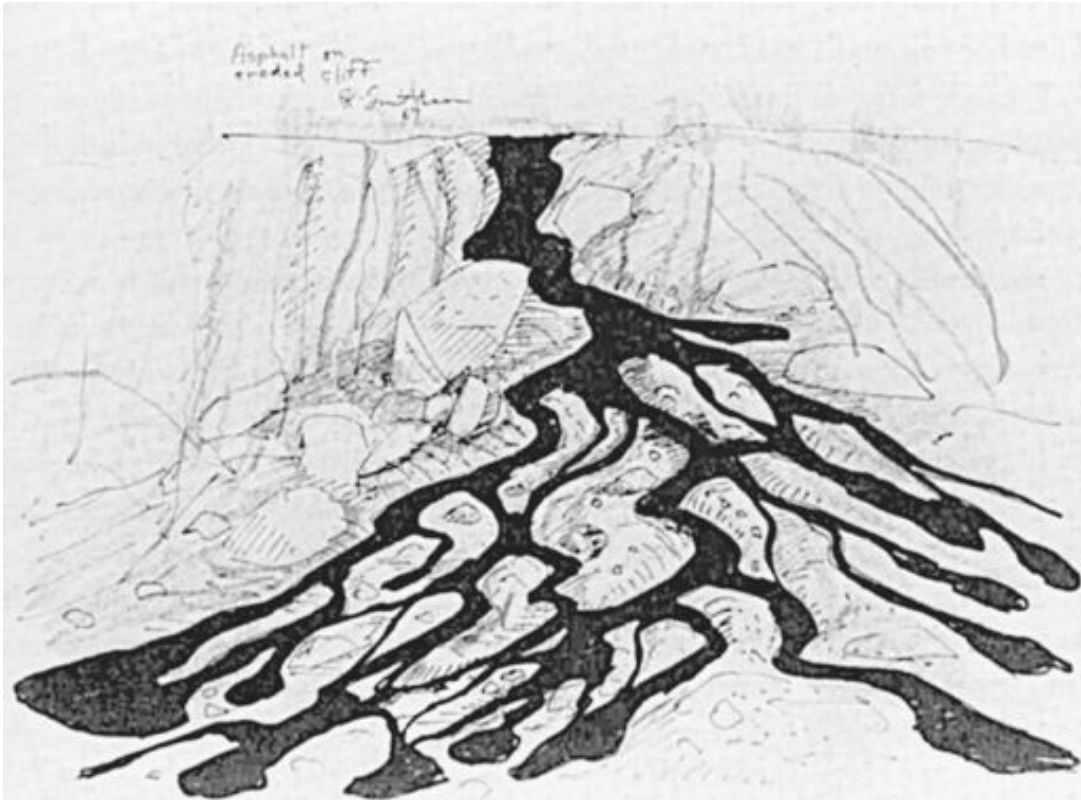

FI G URE 2.

on a surface," but it finally formed into a fixed (and ultimately photographed) image of entropic dispersion, inert matter. "Like a petrified river," as Smithson described his project, its hardened substance had "that sense of something very definitely in time, yet the moment gives you that sense of timelessness. The actual visual experience, perception of that" ("FC," p. 216). "A slow fall," the blackened hill became an opaque picture of arrested writing (recalling the "thick lacquer" of Williams's river, but with nothing "under its flow"). Unlike Williams's falls, here on Smithson's hill there are no words to be heard or read, no lines of language to be untangled, for "the flow is caught," the stream has been silenced, leaving only the vanishing trace of something in time, but timeless, "perception of that."

In his 1967 essay on Passaic (the one that Smithson had suggested could be read as an appendix to Paterson), the artist returns by bus on a day-trip from New York. There he examines what he calls the city's "anti-romantic," entropic landscape, enigmatically describing a region rich in "memorytraces of an abandoned set of futures," the reversible "ruins" rising from the surrounding suburban growth. ${ }^{11}$ Smithson walks alongside the Passaic

11. Smithson, “A Tour of the Monuments of Passaic, New Jersey," Robert Smithson, p. 72; hereafter abbreviated "TM." 
River, just a few miles downstream from Williams's falls in Paterson. Upon an old bridge that crosses over to Rutherford, he looks down at the water below and takes several Instamatic photographs that will later appear as a part of his published essay. From this elevated vantage, he afterwards writes of what he saw, or remembers seeing, recording the conflicted and confused perceptions moving beneath him, images reflecting off the flowing water:

Noon-day sun cinema-ized the site, turning the bridge and the river into an over-exposed picture. Photographing it with my Instamatic 400 was like photographing a photograph. The sun became a monstrous light-bulb that projected a detached series of "stills" through my Instamatic into my eye. When I walked on the bridge, it was as though I was walking on an enormous photograph that was made of wood and steel, and underneath the river existed as an enormous movie film that showed nothing but a continuous blank. [“TM," p. 70]

If the essay on Passaic is indeed to be imagined as an appendix to Williams's already much appended Paterson, then what appears most clearly joined by Smithson to that poem is the increasingly alienating awareness of what, in the radical materialism of his own insight, the region itself will not reveal (fig. 3).

Born of a heightened, almost pathological attention to the indeterminacies of perception, Smithson's vivid descriptions of Passaic present the artist as more and more lost within the city's dislocating play of annulling reflections, his desire to see depleted by his own extended efforts to see anything at all. For the city, instantaneously, has turned itself "into a mirror and a reflection - but the mirror kept changing places with the reflection. One never knew what side of the mirror one was on" (“TM," p. 73). And from the bridge, the river below seems through its very motion to be outstripping its own viewable projection, the flowing waters refusing to show any image at all. If some years before, Williams had stood before this same river looking and listening for language, hoping to discern within its turbulent waters the story of his knowable city, Smithson, years later, finds himself similarly positioned but "completely controlled by the Instamatic" (“TM," p. 70), seeing beneath him "nothing but a continuous blank."

For in Smithson's Passaic, an inundating, blinding force has swept over the city (recalling what Williams himself had seen as the "catastrophe" of the falls), its pictures covering the place, making it virtually unseeable except as image and word. "Seen through a consciousness of temporality,"12 the sense of imminent transformation and disappearance that Smithson re-

12. Smithson, "A Sedimentation of the Mind: Earth Projects," Robert Smithson, p. 112; hereafter abbreviated "SM." 


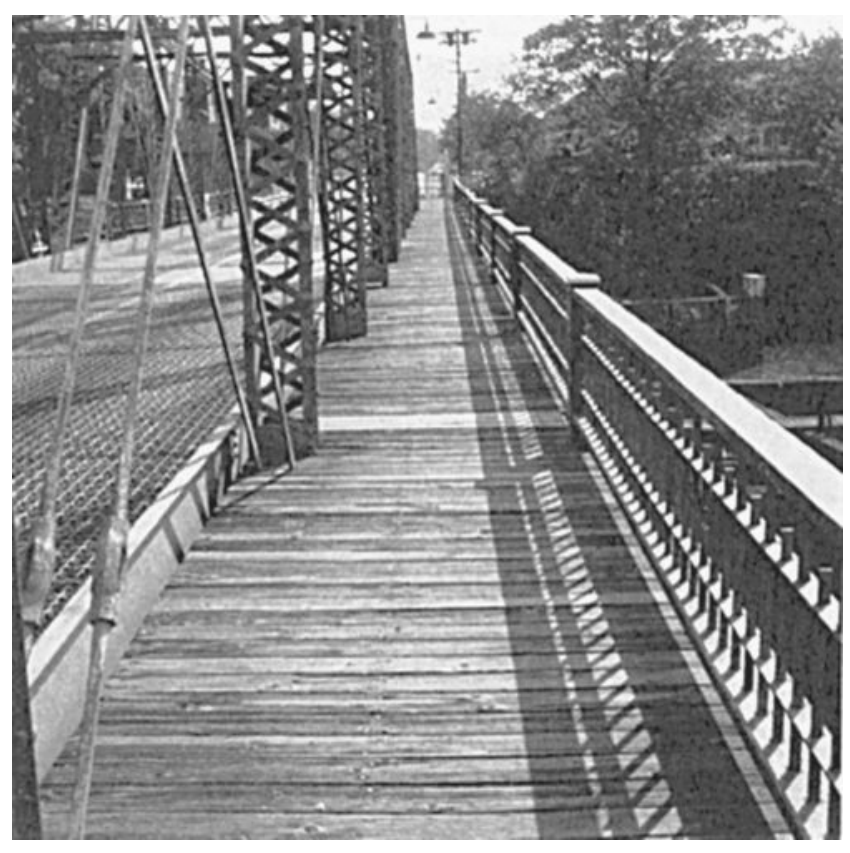

F I G U RE 3 .

cords in his essay, the "quiet catastrophe of mind and matter," is one that, wherever the artist looks, is already well underway and always has been. ${ }^{13}$ "Wandering in a moving picture that I couldn't quite picture," as Smithson says, he is entangled within the very image that is picturing him, but one that nonetheless excludes him from its encompassing image (“TM," p. 72). With the city "loom[ing] like a dull adjective" all around him, it is no longer at all clear what remains to be seen of Passaic, or how, through the obstructing film occluding the eyes, anything is ever to be seen (or said) at all (“TM," p. 72). For the city would seem, even (or especially) in its being seen, to have vanished, with Smithson's pictorialized perceptions of the place immanently edged toward what Williams had earlier called sight's own "vaporous fringe" ("SA," p. 89). ${ }^{14}$

13. Smithson, "Fragments of an Interview with P. A. [Patsy] Norvell," interview with P. A. Norvell, Robert Smithson, p. 194.

14. This tendency on Smithson's part to pictorialize perception as well as his fascination with ruins and found objects is frequently encountered in his work. In particular, in his essay "Frederick Law Olmsted and the Dialectical Landscape" (1973), Smithson outlines his "picturesque" aesthetic with regards to the development of New York's Central Park. This essay offers yet another rich juxtaposition with Williams's Paterson. For here, the "dialectical landscape" of the park-like the landscape of Paterson-is understood as temporally transforming, and one is thus positioned to see "things in a manifold of relations, not as isolated objects" (Smithson, "Frederick Law Olmsted and the Dialectical Landscape," Robert Smithson, p. 160). Smithson's 
Along with (or in spite of) the essay's depicted obstructions to seeing and recording, Smithson presents, regardless, a form of awareness collected like an extracted residue from his own displaced perceptions. For even with perceptual detachment from the scene, he still suggests a necessarily aesthetic attention arising from the ruins of vision. Elsewhere Smithson writes of the turbulence of thought's entropic flow, the corroding confluence of ideas and things:

One's mind and the earth are in a constant state of erosion, mental rivers wear away abstract banks, brain waves undermine cliffs of thought, ideas decompose into stones of unknowing. . . . A bleached and fractured world surrounds the artist. To organize this mess of corrosion into patterns, grids, and subdivisions is an esthetic process that has scarcely been touched. ["SM," p. 100]

As he tries to record the tangible dilapidations of the region, the visible disintegrations caused by the rush of time, Smithson commits himself to the "continuous blank" that is always before him, like an abrasion upon the eye that both conditions and determines his vision. And the "stones of unknowing," as the waters rise, remain both solid and soluble, refusing to speak.

Yet with a form of paraperception or prosthetic seeing, Smithson-walking and looking, taking photographs of photographs-focuses with ever greater intensity upon Passaic's "monumental vacancies" (“TM,” p. 72). And his camera, offering a kind of oblique access, reflects "dialectically" an infraknowledge of the city's dimensional absence. The "bleached / and fractured world" surrounding Smithson fleetingly reveals itself as something about to be seen, giving "passing shape to the unconsolidated views . . . a type of 'anti-vision' or negative seeing," one that finally envisions the scene's very vanishing. ${ }^{15}$

When Smithson writes of "mental rivers ... abstract banks . . cliffs of thought" and the need "to organize this mess of corrosion into patterns, grids, and subdivisions," when he outlines the ambitious undertaking of surveying and seeing a designated site as an "esthetic process that has scarcely been touched," one again recalls Williams and his own endeavor to find a form to accommodate Paterson's changes, a frame within which to see the erosions of a site-

picturesque aesthetic is very usefully discussed in Ron Graziani, "Robert Smithson's Picturable Situation: Blasted Landscapes from the 1960s," Critical Inquiry 20 (Spring 1994): 419-51.

15. Smithson, "Incidents of Mirror-Travel in the Yucatan," Robert Smithson, p. 130. 
- . a mass of detail

to interrelate on a new ground, difficultly;

an assonance, a homologue

$$
\text { triple piled }
$$

pulling the disparate together to clarify

and compress

$$
\text { [P, p. 19] }
$$

As the four parts of Williams's long poem were consecutively published-1946, 1948, 1949, 1951—Paterson was both well received and widely criticized, finally granting the poet some limited renown but also exposing him to various types of analysis and objection. In particular, the poem's collaged structure was cause for concern; its recurring placement of prosaic artifacts alongside and interrupting the more conventional-seeming poetry alarmed many as an inelegant intrusion into Paterson's otherwise lyrical form, its pictures of Paterson, distracting from the poem's powerful and often poignant insights. In correspondence to friends, Williams responded to many of these criticisms, writing that those sections of disparate prosethe fragments of civic documents, passages from personal letters, old newspaper clippings, long listings of accumulated local data-were not intended as material for facile provocation, they were "not an antipoetic device," but instead these sections were extracted-or excavated-from the city itself, inserted then directly into the poem, as the poem, in order to materially affirm "that prose and verse are both writing." Like a found object picked up from the ground, or perhaps a Duchampian readymade that has been almost indifferently designated, the varied prose artifacts were there to demonstrate that "poetry does not have to be kept away from prose . . . it goes along with prose and, companionably, by itself, without aid or excuse or need for separation or bolstering, shows itself by itself for what it is. It belongs there, in the gutter." 16

Yet Williams, in spite of his best defenses, was no doubt well aware that his growing poem was structurally straining. Indeed, he was to frequently question Paterson's very cohesion and continuity, its own elusive conclusions, acknowledging in the poem's 1951 preface that a major concern all along had been "how I was going to end the poem" $(P, \mathrm{p}$. xiii). As a reflection of this very uncertainty, the poem's originally envisioned four parts, once published, almost immediately gave way to a fifth, the poet beginning again to gather new material, as Paterson appended further and further out from itself. For like Smithson's later Passaic, Paterson's very picturing seemed to disallow any final, fixed frame, the city forever deferring into its own con-

16. Williams, letter to Parker Tyler, 10 Mar. 1948, The Selected Letters of William Carlos Williams, ed. John C. Thirlwall (New York, 1957), p. 263; hereafter abbreviated S. 
stantly occurring differences. Its patterns reconfigured, its lines redrawn, the ground beneath the city refused to stay still, withholding from Williams "the radiant gist ..., the final crystallization" ( $P$, p. 109). Meanwhile, other extratextual obstacles were emerging more and more forcefully at this time for Williams, as the aging poet's own mortality was making itself increasingly felt. A series of strokes in the 1950 s was beginning to vividly signal other conclusions, other endings adjacent to the poem's own.

Williams's ongoing search for both an enduring structure to the poem and an appropriate conclusion to what seemed increasingly, inherently unconcludable appears to have given way again and again over the years to moments of great frustration and even despair. Indeed, earlier he had written, when the poem seemed once more to be spiraling out of control, "I wish I had the guts to say to burn the whole Paterson script" (quoted in "P," p. xi). In a letter to Allen Ginsberg (born in Paterson), Williams acknowledged that "I don't even know if Paterson is poetry. I have no form, I just try to squeeze the lines up into pictures." ${ }^{17}$

One of the found documents in book 3 of Paterson appears in particular to have caught the eye of Robert Smithson: a nineteenth-century verbatim record of drilling into the substratum of rock and sand lying beneath the city. This was the specific section of Paterson that Smithson later alluded to when he spoke of Williams's poem as a piece of "proto-conceptual art," a document that the artist was perhaps inclined to see as a kind of written account of an early earthwork dug deeply into the ground. Taking up an entire page, this section of Paterson is an example of the type of prose artifact that mystified, or even alarmed, many of its readers. For it is unclear, in suddenly coming upon this thing in the text, what the writing is intended to accomplish, what we are actually supposed to do with it: read it, line by monotonous line? look at it, as a kind of excavated object placed on the page? glance at it, getting it, before quickly moving on to the rest of the writing? ignore it almost entirely (as I had the first couple of times that I read Paterson)? In various areas of book 3, the act of reading and the look of language present themselves as being deeply conjoined, linked indeterminately as if to some form of subterranean confluence. Indeed, just prior to this passage are two pages in which reading itself has been both directly addressed and performatively engaged, in which the printed lines on the first page have gone from being literally jumbled in their layout (as if the ground beneath them had shaken), to rigidly stratified on the second page, settled into compacted arrangement. ${ }^{18}$ Yet ways of approaching Williams's

17. Allen Ginsberg, Journals: Early Fifties Early Sixties, ed. Gordon Ball (New York, 1977), p. 4.

18. On the stratified page next to Williams's list, in a kind of transliteration of a folksy vernacular, we read (in apparent reference to the mention of Antonin Artaud on the jumbled page 
found document nonetheless remain uncertain, even though its placement and prominence would seem to indicate that the page is not simply to be passed over, that this piece of writing must finally, in some manner, be attended to (fig. 4).

Keeping in mind Williams's own frank admission that in Paterson he is squeezing the lines of his otherwise formless writing "up into pictures," we might wonder what these "squeezed" lines are indeed picturing, what we are being directed to see in this easily overlooked document? And what, in our ongoing questioning of the bond between the poem and the placePaterson and Paterson-are these pictures then telling us about these two indeterminately related sites?

For here is a detailed record of the very ground beneath the city itself, the supporting, stony structure upon which the poem was to unfold, a literal bedrock. It's almost as if the language alone was intended to move us into the hardened ground, the words boring further and further through layers of stratified stone, until, as the record shows, the drilling, and presumably our reading, must be finally "abandoned." Like compacted specimens of extracted earth, the language, by the determinable point of the "shaly sandstone" at "2,100 feet," can go no further, coming up empty, the words, like the water found at that depth, "being altogether unfit for ordinary use." But in taking Williams at his word and reading what's before us, just how deeply can we actually go with the writing and at what point in the tabular account do the words themselves begin to weaken? How far can our "energized ... imagination" ("SA," p. 138) take us before we begin to question the very visibility of the picture presented, before we-as Smithson had experienced while looking down at the Passaic River-draw a "blank"?

Perhaps we can approach it another way: Williams's long list might be seen as a kind of objective performance, or parody, of the whole idea of profundity itself, of digging hermeneutically ever more deeply to uncover greater degrees of accuracy, fact, truth. For the lines of this list, intended perhaps to transport us down through the ground (as if through some kind of conceptual mine shaft), take us finally where, towards what? With tongue perhaps partially in cheek, it's as if Williams were saying, "You want depth? I'll give you depth. Just look how far down I can go. You want to know more about the ground beneath Paterson? Here is a carefully calibrated listing of all that lies beneath it, the very underpinnings of the poemed place laid out with empirical precision as a kind of three-dimensional abstract map, its

just preceding this one): "I never told you to read it. / let erlone REread it. I didn't / say it wuz!! henjoyable readin" ( $P$, p. 138). One wonders if this bit of roguish advice was to be directed, if only in part, towards the larger poem itself, or even perhaps more specifically, the tabular list of data on the adjacent page. 


\section{SUBSTRATUM}

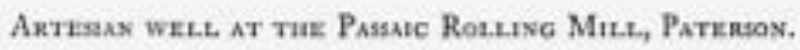

The following is the tabular account of the specimens found in this well, with the depths at which they were taken, in feet. The boring began in Septeraber, 1879 , and was continued until Noveraber, 1880 .

\begin{tabular}{|c|c|c|}
\hline DErTt & & DEscarrmon of statrates.s \\
\hline 65 feet. & . & Red sasdstooc, fine \\
\hline 110 feet. & . & Red sandstone, course \\
\hline 182 foet. & . & Red sandstone, and a little shale \\
\hline 400 fect. & - & Red sundstone, shaly \\
\hline 404 feet. & - & Shale \\
\hline 430 feet. & . & - Red tandstose, fine grained \\
\hline 540 feet. & . & . Sandy shale, toft \\
\hline 565 feet. & . & . Soft shale \\
\hline 585 feet. & . & - Soft shale \\
\hline 600 feet. & & - Hard sandstone \\
\hline 605 feet. & & . Soft shile \\
\hline 609 fect. & & - Soft shale \\
\hline 1,1 , o feet. & . & . Selenite, $2 \times 1 \times 1 / 16$ in. \\
\hline$t, 180$ feet. & . & . Fine quicksand, reddish \\
\hline I, 1 Bo feet. & - & - Pyrites \\
\hline 1,370 feet. & . & . Sindy rock, under quicksand \\
\hline 1,400 feet. & . & . Durk red sandstone \\
\hline$t, 400$ feet. & - & - Light red sanditone \\
\hline$t, 415$ feet. & . & - Durk red sandisone \\
\hline 1,415 feet. & , & . Light red sanditene \\
\hline 1,415 feet. & - & . Prugments of red sundstone \\
\hline$t, 540$ feet. & . & - Red sandstone, and a pebble of kaolin \\
\hline$t, 7 \infty 0$ feet. & . & Light red sundstone \\
\hline 1,830 feet. & . & . Light red sandrtone \\
\hline 1,830 feet. & . & - Light red sanditone \\
\hline 1,830 feet. & . & Light red stone \\
\hline 2,000 feet. & - & . Red shale \\
\hline 2,020 feet. & - & - Light red sanditone \\
\hline 2,050 feet. & - & 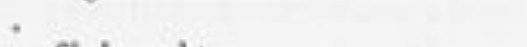 \\
\hline 2,100 feet. & . & - Shaly sandstone \\
\hline
\end{tabular}

At this depth the attempt to bore through the red sandasone was abandoned, the water being altogether unfit for ordinary ve. . . The fact that the rook salt of England, and of tome of the other salt mines of Europe, is found in roeks of the same age as this, raies the question whether it may not alto be found here. 
measured markings corresponding to the dark underworld below. Can you see it there on the page, the words boring profoundly into the ground?"

With such deep digging, and the language line by line seeming undermined by its own collapsing dimensions, where does this list finally leave us? For the machinery of language moves us only so far, the words like wornout drill bits breaking from the density of the site's imagined depth. ${ }^{19}$ And, in the final account, what have the words of this document most vividly pictured as they're squeezed ever more tightly onto the white paper, leaving the language to look increasingly not only like a kind of protoconceptual art but also like a protoconcrete poem? In many respects, the words appear to picture themselves picturing, returning us (as if for air) to the surface, undeceived, to the solid ground of the printed page itself. As Williams wrote, not far from this document in Paterson, offering perhaps an instructive way of seeing the reading, reading the site:

Let us read

and digest: the surface

glistens, only the surface.

Dig in-and you have

a nothing, surrounded by

a surface, an inverted

bell resounding

the emptiness of

a cavern resounding

$$
\text { [P, p. 124] }
$$

The conceptual aspect of Paterson that Smithson was perhaps most strongly drawn to was the manner in which this old document of the city's substratum points the reading mind towards a kind of unfathomable depth, into an aporia of a registered but finally unimaginable site, one that, as Smithson says elsewhere of his own work, "is evading you all the while it's directing you to it. ... Although it's in the physical world, it's not there" ("FC," p. 218). Like one of Smithson's Non-sites-a container of extracted stone from a specific area (often New Jersey) placed in an art gallery alongside maps and photographs-Williams's list seems to signal a specific place in Paterson, while setting up an "unresolvable dialectic" 20 in which both the

19. On the page just following this list, we immediately read "FULL STOP." Boldly, the punctuation mark has been written out, perhaps as an unsuccessful attempt to halt the constant movements of language. But the full-capped words are read now much like a road sign ignored, passed on through to the many pages that seem only to keep on coming.

20. Robert Hobbs describes Smithson's aesthetic method as engaging an "unresolvable dialectic" in which the terms of his investigation never succeed in synthesizing toward some apex 
signifier and the signified, the place and the poem, instantly vanish in the very attempt to picture them, leaving one, as Smithson wrote, "confronted with a very ponderous, weighty absence." ${ }^{21} \mathrm{He}$ went on to describe powerfully the fraught phenomenon of naming unstable substances, applying words to eroded forms:

The names of minerals and the minerals themselves do not differ from each other, because at the bottom of both the material and the print is the beginning of an abysmal number of fissures. Words and rocks contain a language that follows a syntax of splits and ruptures. Look at any word long enough and you will see it open up into a series of faults, into a terrain of particles each containing its own void. ["SM," p. 107]

Williams's names of the minerals and the minerals themselves lying beneath Paterson may also be imagined — at some point, at some level—as splitting and fissuring, the material and the print loosening their hold. Boldly registered as a kind of printed matter, language itself is also now seen as equally susceptible to the active processes of entropic dispersion. Neither hovering mystically on high nor hiding hermetically below, the words have been abruptly returned to earth, grounded, and subsequently exposed as both materially vulnerable and semantically contingent. And, in looking long enough at Williams's words, we may indeed begin to discern what he, some pages before, had described as a kind of limit to language, a loss of the readably real.

closing about the mind

$$
\text { (a slowly descending veil }
$$

cutting the mind away)

SILENCE!

$$
[P, \mathrm{p} .101]
$$

In his autobiography, writing about the specific image of depth, Williams directly responds to some of his critics and their concerns with his insistent attachments to surface, addressing their charges of an absence of deep ideas to accompany the presented image or object. Almost scornfully, he reveals his distrust of "their profundities," affirming a differently spatialized model of thinking that instead of metaphysically extending down into the fabled depths uses words to more thinly laminate a thought onto an object-an idea onto a thing. The language, spread like translucent water across the

of achievement, but instead remain forever uncompleted. "His art could be called the art of unresolvable dialectics.... Smithson constantly strove to achieve a state of indeterminacy in which meanings are projected as well as canceled out" (Robert Hobbs, "Smithson's Unresolvable Dialectics," in Robert Smithson: Sculpture, ed. Hobbs [Ithaca, N.Y., 1981], p. 23).

21. Smithson, "Fragments of an Interview with P. A. [Patsy] Norvell," p. 193. 
more immanent plane of a page, projects laterally an unreality, one that is vaguely adjacent to the real. The city and the poem are both there and not there, seen and not seen, mirroring, but in the very instant of their reflecting, overexposing, dissolving. ${ }^{22}$ Yet the words somehow remain-like a residue of the real, its faint chafing - the material components of a carefully crafted hallucination. Williams writes:

But the critics would have it that I, the poet, am not profound and go on with their profundities.... [But] it all depends on what you call profound.... They think, and to think, they believe, is to be profound.... But who, if he chose, could not touch the bottom of thought? ... The poet thinks with his poem, in that lies his thought, and that in itself is the profundity. The thought is Paterson, to be discovered there. ${ }^{23}$

Paterson and Paterson, the two appear to point to each other but never quite coincide. The site of the city and the nonsite of the poem reflect at oblique angles aspects of one another, while retaining always that unbridgeable breach between-lines refusing to line up. The selected city was an imaginary place that was also, apparently, very much real. But, as Williams writes, it was equally real as imagined, real in the writing-as real as the marks on a map, a container of gathered stone, a person seen in a photograph. Paterson was typed out letter by letter onto the landscape of the white page, pictured onto blank paper, while the unitalicized city itself was, as a matter of fact, unmoved, left largely alone. Williams elsewhere described what his language was intended to do, "the poet's business" of using words like machine parts, their cantilevered forms as primary as steel, extending out from themselves and over a finally unfathomable chasm - the poet resigned and resolved to "invent reality in the words which stem back directly to things, to the ground, to his own simplicity, directness, and after all emptiness." 24

Various other writings by Smithson suggest further affinities with Williams, and Paterson in particular, where seeing and saying appear complexly conjoined. ${ }^{25}$ A section of “The Spiral Jetty” (1972), one of Smithson's better

22. Such disruptions of perception recall Smithson's sculptural wall-piece made with mirrors and minimalist metal, Enantiomorphic Chambers (1964), in which viewers, positioned to see their own reflections, see nothing at all. There is no small irony in the fact that this early Smithson sculpture, like the Spiral Jetty for so long vanished beneath the Great Salt Lake, has since been lost.

23. Williams, The Autobiography of William Carlos Williams (New York, 1967), pp. 390-91; hereafter abbreviated $A$.

24. Williams, "Shakespeare," The Embodiment of Knowledge, p. 16.

25. One thinks, among others, of such works as Strata: A Geophotographic Fiction (1970-71), with its composed layout of photographs of stone and fossils that are representative of different geologic time periods, interspersed with blocks of writing, a series of words and phrases, 
known essays, seems particularly striking and relevant in this regard, offering a richly readable parallel to Williams's document of Paterson's substratum. At the very center of his essay, Smithson describes what he saw standing at another center, the one at his just completed project at the Great Salt Lake in Utah. ${ }^{26}$ With a kind of mesmerizing redundancy, he moves through the twenty points of the compass, noting the four recurring elements that make up the landscape before him. Formally, Smithson's tabular list stands out from the rest of the writing, an essay that otherwise focuses upon Spiral Jetty's construction, alongside theoretical meditations upon time, matter, and the "actualities" of perception. Again, the reader is left to determine how this textual thing is to be handled (fig. 5).

As with Williams's account of deep drilling, we might try to imagine Smithson standing within Spiral Jetty, pivoting his feet by slight degrees upon the rocky ground, observing and recording the view before him. With the landscape extending in all directions at once, the same sight is seen, again and again, from here, from there, and the same words, over and over, are telling us the same thing-mud, salt crystals, rocks, water. Yet in looking at this long list and trying to see what is said, how do we transfer or translate the words that are printed on the page into a receivable message, a conceivable image? From the center of the earthwork, from the center of the essay, what are Smithson's descriptions describing, what are his words leading our eyes towards? Cast before us as the record of the landscape, is it matter or mirage (or an entangled collusion of the two) that the language of this list is finally picturing?

Whereas Williams's document had taken us down deeply into the ground, Smithson's has us looking horizontally in all directions. The words of this list, moving from line to line, in their progressive accumulation, tell us less and less about the site being described. For with each incremental shift of direction, Smithson's repetitions produce a kind of incantatory dissolution of sense in their uncanny piling up, ad nauseam, of identical information. And, rather than granting us a trusted vantage from which to envision and understand our view, the lengthening series of lines cancels out that which spatially it seems to be saying. We read the repeated words

interrupted by quotations; Pulverizations (1966), in which arcane symbols and equation-like formulations are listed alongside designations of particular types of stone; and A Heap of Language (1967), where the text, handwritten into the shape of a pyramid, is made up of a variety of linguistic terms that name various forms and uses of language itself, "operat[ing] between," as Smithson writes elsewhere, "literal and metaphorical signification" (Smithson, "Language to Be Looked at and/or Things to Be Read," Robert Smithson, p. 61).

26. I discuss my own travels to the Great Salt Lake to try and find the Spiral Jetty in Clark Lunberry, “Quiet Catastrophe: Robert Smithson's Spiral Jetty, Vanished,” Discourse 24 (Spring 2002): 85-120. 
From the center of the Spiral Jetty

North - Mud, salt crystals, rocks, water

North by East - Mud, salt crystals, rocks, water Northeast by North - Mud, salt crystals, rocks, water

Northeast by East - Mud, salt crystals, rocks, water

East by North - Mud, salt crystals, rocks, water

East - Mud, salt crystals, rocks, water

East by South - Mud, salt crystals, rocks, water

Southeast by East - Mud, salt crystals, rocks, water Southeast by South - Mud, salt crystals, rocks, water

South by East - Mud, salt crystals, rocks, water

South - Mud, salt crystals, rocks, water

South by West - Mud, salt crystals, rocks, water Southwest by South - Mud, salt crystals, rocks, water Southwest by West - Mud, salt crystals, rocks, water

West by South - Mud, salt crystals, rocks, water

West - Mud, salt crystals, rocks, water

West by North - Mud, salt crystals, rocks, water Northwest by West - Mud, salt crystals, rocks, water Northwest by North - Mud, salt crystals, rocks, water North by West - Mud, salt crystals, rocks, water

FI GURE 5 .

until they sound (and look) increasingly strange- the familiar made foreign, the readable unreadable_-as if the accustomed meanings, once touched by our eyes, break beneath the burden of the recurring lines themselves. Like an aporia of worded sight, this annulling of the described picture at the Great Salt Lake is accomplished, however, not through a crossing out or effacement of the words, but instead through a Stein-like excess of repetitive evidence, an absurd redundancy of data. Both there and not there, 
speaking and not speaking, the language-convolutedly (or spiraling)— points like a signpost back to itself pointing.

As we saw with Williams, Smithson and his monotonous list enact a kind of parody of listing (and perhaps language) itself, suggesting that the view surrounding him can neither be faithfully recorded nor read, that words cannot be found to accurately fix the sight onto the scene. The precision of the written directions and descriptions - an exhaustive inventory of all points of the compass-would seem to thus delineate the contours of a kind of vortex that negates any notion of a center at all, the place from which the list began, the spot from which Smithson stood. At the site, on the page, matter and mirage colliding, what is seen cannot be said, what is said cannot be seen. And of the language, by default forming a kind of pseudocenterits capacity (or incapacity) to capture and contain in mind-Smithson punningly observed, "One seizes the spiral, and the spiral becomes a seizure," dispersing into a flurry of equivalent words. ${ }^{27}$

Yet as the language of Smithson's list weakens and its familiar meanings dissipate, the visual fixity of the words on the page-their ink-filled placement there on the printed paper-has simultaneously strengthened, becoming oddly emboldened. Estranged, the lines nonetheless are increasingly obdurate and materially present, crystallized by the repeated patterns, the inert letters conspicuously shaped and arranged-meaning less, but appearing more. Read and seen like a concrete poem, Smithson's list looks suddenly like a layering of strata laid out upon the page. And what Smithson wrote of his friend Carl Andrés block poems effectively describes his own list (as well, perhaps, as Williams's), in which the "writings bury the mind under rigorous incantatory arrangements. ... smother[ing] any reference to anything other than the words. Thoughts are crushed into a rubble of syncopated syllables. Reason becomes a powder of vowels and consonants. His words hold together without any sonority. ... Semantics are driven out of his language in order to avoid meaning." 28

Elsewhere in "The Spiral Jetty," Smithson spoke directly about finding words to wrest perception into fixed form: "The equation of my language remains unstable, a shifting set of coordinates, an arrangement of variables spilling into surds. My equation is as clear as mud-a muddy spiral." ${ }^{29}$ For in spite of the list's insistent defining, its persistent pointing, there is no center to Spiral Jetty, and, as a consequence of its absence, no center for the one seeking it. As Gary Shapiro writes of Smithson's investigations of such a site, of such avoided voided meaning,

27. Smithson, "The Spiral Jetty," Robert Smithson, p. 147.

28. Smithson, "A Museum of Language in the Vicinity of Art," Robert Smithson, pp. 79-80.

29. Smithson, “The Spiral Jetty,” p. 150. 
The loss of a psychological center is one consequence of the general failure of organizing principles.... What Smithson explores is a specifically linguistic form of self-loss. He tells us that "each word contains its own void" and warns us of the "voids of knowledge" that lie in wait for the artist who explores the labyrinths of language. Constituted as speaking subjects, we are all containers of our own voids, in thrall to the language that speaks us. ${ }^{30}$

The directions and descriptions intended to take us to Smithson's earthwork, to picture the place, dissipate under the weight of their own signifying burden, the "words," as Smithson elsewhere described them, "caught in your eyes." ${ }^{31}$ Recalling once more Williams's Passaic Falls pouring destructively, catastrophically down, Smithson wrote:

This discomforting language of fragmentation offers no easy gestalt solution; the certainties of didactic discourse are hurled into the erosion of the poetic principle. Poetry being forever lost must submit to its own vacuity; it is somehow a product of exhaustion rather than creation. Poetry is always a dying language but never a dead language. ["SM," p. 107]

In a watery site, at a location of dissolving language, Smithson stood looking out from Spiral Jetty, while many years before Williams had stood listening next to the Passaic River of Paterson. Dying but not dead, the language of Paterson was precisely printed onto the white page, the poem and its typed words made like a machine by a machine, vividly registering the visual significance of the poem, its look upon paper. Both shaped and seen, the words like found objects were in this made manner clearly rendered as malleable, meaningful material—all writing now, listed or lyrical, as a kind of concrete poetry. Yet as material, the language's vanishing presence was to be more conspicuously conceived as subject to-like all else- - a kind of mortal pull, the forces of dissolution and entropy ultimately encroaching, overtaking the language itself. With this retrieved language, Williams was nonetheless determined "to say what must be said; to say it once that it may blossom once like a hollyhock or a bird — then let it begin to die-even while he himself is alive he will see his own writing grow older and begin to die. He may live to see it completely dead." 32

Later, posthumous editions of Paterson open with a full-page, black-andwhite photograph next to its title page of Williams high atop a hill that over-

30. Gary Shapiro, Earthwords: Robert Smithson and Art after Babel (Berkeley, 1995), p. 177.

31. Smithson, "A Museum of Language in the Vicinity of Art," p. 80.

32. Williams, "Afraid lest he be caught in a net of words," The Embodiment of Knowledge, p. 105. 
looks the city of Paterson (fig. 6). An old man at the time the picture was taken, he sits upon a large rock, hand to his chin, looking either bemused or bewildered, lost in thought (or perhaps merely made self-conscious by the photographic pose briefly required of him). In many ways, however, this mundane snapshot of Williams, and the city below, can be read as if reflecting something of the particular task that he had set for himself when, years before, he undertook to begin his long poem, to write about his "selected" city of Paterson "as my reality" ( $P$, p. xiii). For over his shoulders, the city is presented in a kind of encompassing perspective, granting from its elevated vantage a contained view of its many buildings and streets, parking lots and empty sidewalks, the cars on the road unmoving. Photographed, Paterson is here seen as the selected place that it was, settled and steady, like a held thought fixed upon the page, awaiting its own pictured transcription.

From Paterson's very inception, "centering upon the poem," Williams desired "to find an image large enough to embody the whole knowable world. . . . as a physician works, upon a patient. . . . I took the city as my 'case' to work up, really to work it up. . . . In the very lay of the syllables Paterson as Paterson would be discovered, perfect, perfect in the special sense of the poem, to have it" ( $A$, pp.391,392). With Paterson thus conceived as an "image" to be found, a body to be examined, the place and the poem were to somehow collide and converge into collaged form, one that was then to be seen as a whole, a syllabled object that could finally be looked upon and read as real. The words would make the place, the place would make the poem. And if, as Williams insisted again and again in the opening pages of his poem, there were to be "no ideas but in things," then here was such a thing in the making $(P$, p. 6). Made in the mirroring (and only in the mirroring), the poem and the place were to reflect, affirm, create the worded image, the material apparition. Seen upon the page as if from a tall hill, the city might thus appear, collapsing into flattened dimension, "just therefor a split second-from one side or the other, it has fluttered before me for a moment. . . . it comes, it is there, and it vanishes. But I have seen it clearly. I have seen it. I know it because there it is" (A, p. 289).

On the day that Williams was photographed, however, with his ongoing poem having enlarged and spread far beyond expectations, what might the poet, now near the end of his life, have seen looking down below at his chosen city? Laid out before him, what had become of his found "image," his "patient" Paterson, that, always exceeding itself, was never to be quite completed, never fully, perfectly discovered? For shifting and sprawling, the city would not stay still, and the Great Falls at its center-those raging waters that he had earlier described as "the lucky burden of what I wanted to 


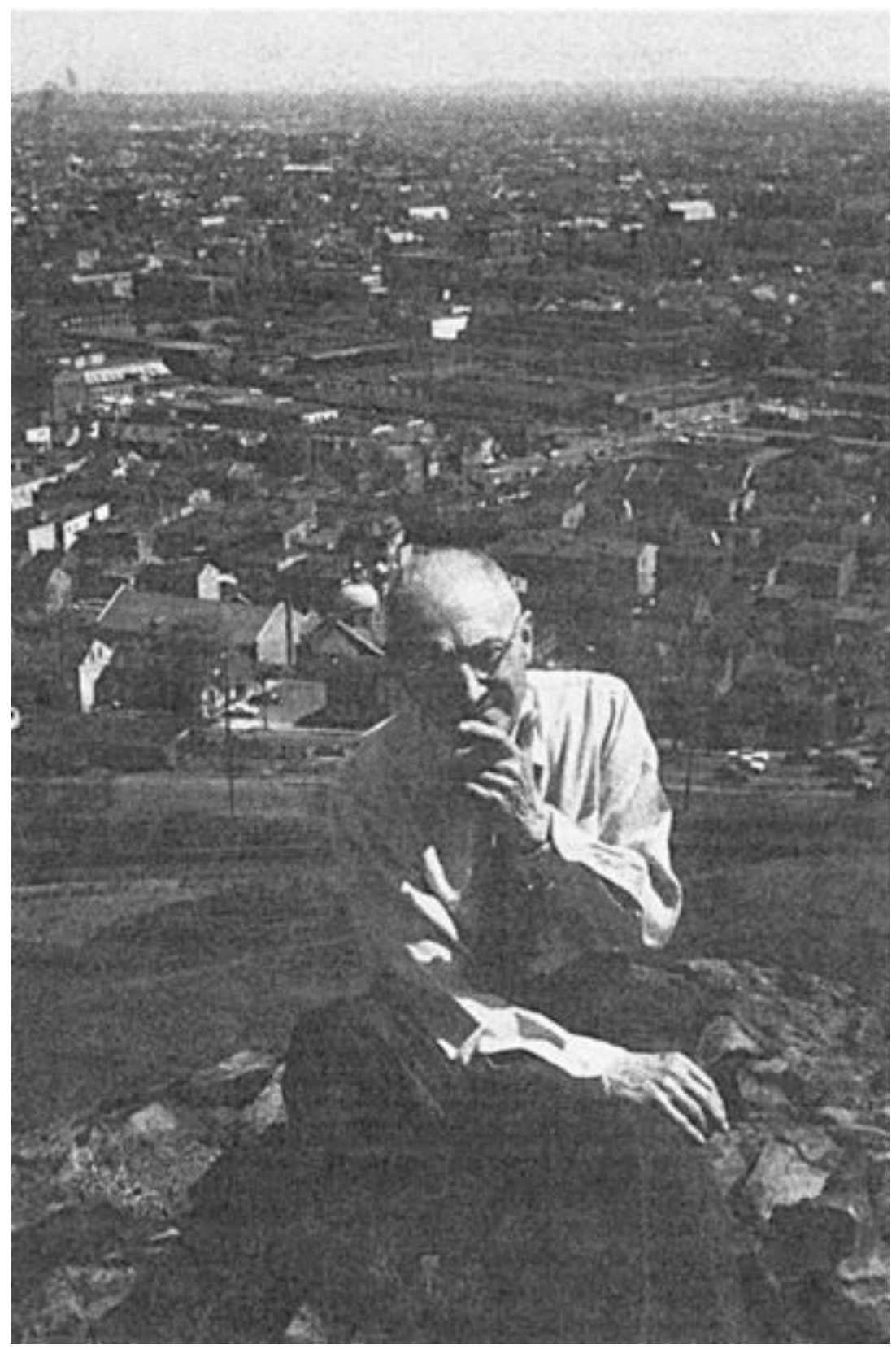

FIGURE 6 . 
say"-would only keep coming, pouring down. Could it be that Paterson had ultimately proven itself to be too much of a thing for it to finally be fixed, to fully be said, the city always outstripping its own narration? As Williams was to write in his later, fifth book of Paterson, sounding here a note of resignation, of fateful recognition: "The brain is weak. It fails mastery, / never a fact" $(P, \mathrm{p} .190)$. And Paterson, in some final account, would appear to have become the poignant record of an impossible knowledge, an unsustainable image, always requiring additional appendices for its story to even be partially, provisionally told. Like Smithson stranded at the center of his own centerless earthwork, Williams was now left at the falls that had begun as the "lucky burden" of his poem, realizing and perhaps reconciling himself to the indomitable dimensions of the burden before him.

Recalling that Paterson had in part originated as the search for "an image large enough to embody the whole knowable world about me," we might now regard the photographed poet as an inextricable part of the poem's ever-enlarging image, an extratextual dimension to the poem itself. For within the photograph, Williams - his struggles, his successes, his body and its image - can be seen to have ultimately become a part of the poem's enlarged picture, its collaged configuration, with this photograph appended onto the remainder of the already heavily appended poem, indeed affixed to its title page. Williams's Paterson, reflecting like a photograph, thus reveals but a momentary arrangement of events that includes both a picture of the city and the poet who had tried to picture it. For in time's inevitable displacements, the patterns of this place, this city, were constantly reconfiguring-Paterson's inhabitants appearing and disappearing, its buildings rising and falling, the very ground beneath it, deeply, silently shifting. And like trying to make a map of motion itself, the lines of the city could only be continually redrawn, its boundaries pushed and pulled, its interior reconfigured. For the very substance of this place was forever being reformulated, dislocated, its name alone-Paterson-remaining singular and constant. The city seen below, in order to be seen at all, would have to be pictured over and over, the photograph taken again and again.

We have already seen such endless photographing of a city in Smithson's own appendix to Paterson, "The Tour of the Monuments of Passaic, New Jersey." There he had similarly found himself within an image, "walking on an enormous photograph. . . . wandering in a moving picture that [he] couldn't quite picture." Therefore at these two sites-Paterson and Passaic_-where the nexus of Williams's and Smithson's engagement with one another finally comes more clearly into focus, the stakes of their juxtaposition are most vividly revealed. 
While Williams, in Paterson, sought endlessly, one might even say heroically, "to find an image" of his selected site, to "know" the place, to "have it," Smithson, later on, investigated and uncovered very different aspects of nearby Passaic and, as a result, drew quite different conclusions. For as Williams selected the city of Paterson as his "reality" because he imagined that it might finally be "something knowable" ( $P$, p. xiii), then Smithson, years later, selected Passaic for overlapping, but opposite reasons - the place's very unreality, its insistent unknowability. Two sides of the same coin, the same region: Williams sought in his city, however impossibly, the steadied development and stilled life of a picturable place and person emerging, "a man in himself . . . a city, beginning, seeking, achieving and concluding his life" (an impossibility that, year by year, was to manifest itself materially through his very inability to complete his poem, to close the book upon Paterson); while Smithson discovered in Passaic a more consuming and sprawling series of interfering images, an amorphous site of natural flux and uncontrollable change where even in the growth there were ruins; even in life, loss.

On that afternoon of his visit to the region, Smithson was not to find a single image of Passaic (as Williams had ultimately sought in Paterson), but many; for wherever he was to look, the pictures only kept on coming, accumulating. And marking what might now be understood as a kind of perceptual, ontological threshold (as well as perhaps a generational, historical divide), Smithson was not—unlike Williams—-to resist or reject the proliferating images, the "unconsolidated views" before him. Instead, he was to endeavor to photograph them, as if by acquiescing to the seemingly infinite play of reflections he might somehow find access to the very mechanisms of the pictures' projections. For Passaic's “over-exposed" pictures, as if preceding their own appearance, were continually thrusting themselves before his eyes, and their own cast images were thus received before they could ever be seen, made instamatically into photographs of themselves (and thus leading to the uncanny act of trying to photograph that). Consequently, rather than attempt to reconstruct what was seen-what he elsewhere recognized as "a vain exploit" - Smithson was to wonder whether one might instead be better off "reconstruct[ing] one's inability to see." 33

Through the camera, its lens now immanent to the eye, Smithson was made dialectically aware of the movements of disappearance before himpictures passing, coming into focus, and fading uncontainably away. And this incessant displacement of images was ultimately to determine, as if by default, the delimited range of his insights, his perceptions exhausted in the 
energy needed to see them. "Under the dead light of the Passaic afternoon," Smithson thus took his "listless, entropic snapshots," unable to see the site before him without seeing himself see it, without always seeing himselflike Williams photographed overlooking Paterson-within the city's already doubled dimension. Indeed, one might even say that in his desire to see the city, to photograph it, his very vision had become occluded by the stretching and straining of sight towards its own tethered limit, creating a kind of afterimage of absence imprinted like an undeveloped, undevelopable photographic negative onto the delicate cornea of the eye. Here, ultimately, Smithson was not simply seeing entropically, but the seeing itself had become entropic. Or as he elsewhere noted, "To see one's own sight means visible blindness." ${ }^{34}$ Beneath the bridge extending over to Williams's Rutherford, the river flowed (like a "blank" film), its cataracting waters connecting the city of Passaic to Paterson. But the projected images—seen negatively now with a kind "anti-vision" — were to show finally, most vividly, something of their own unmaking, the pictures breaking up and dissolving, momentary markings "charged with the rush of time" ("SM," p. 112).

By the early 1960s, to tell his story of Paterson, and to keep telling it, Williams was rapidly running, not out of material (for that was a large part of the problem), but out of time. However, not long after, unexpectedly, so was Smithson. Off he went, in 1973, to build Amarillo Ramp in Texas, hiring a plane to fly him up over the location of the piece, joined by a photographer so that pictures could be taken of the staked-out work below. No photographs were apparently ever retrieved from the site of the deadly crash. And Smithson's sudden, unforeseen passing is now routinely referred to as "untimely."

In a 1958 letter to his publisher (the same year that the young Robert Smithson was to visit him in Rutherford), Williams, then seventy-five years old and far from well ("palsied," as Smithson described him, as a result of his several strokes), writes again about the difficulty of ever finishing Paterson: "I have been forced to recognize that there can be no end to such a story I envisioned with the terms which I had laid down for myself" ( $P$, p. xiv). And at his death, in 1963, found among Williams's papers were the beginnings of yet another section, book 6 . An unfinished typescript, only a few pages, but on its first page, the following line:

Words are the burden of poems, poems are mad of wods 
The aged poet, struggling now through his various ailments to correctly type the words, misses keys, jams the letters, and burdensomely enacts the very essence of the line that he is trying to type. The words of the poem, like the Great Falls at its center, had indeed become the burden of this great project upon which so much was finally to depend, the unruly material of which Paterson was to be made. And in the poem's faltering, poignantly registered and seen on the printed page, Williams's last lines signal the de facto end of the story, the poet himself no longer able to type another word.

\section{Coda}

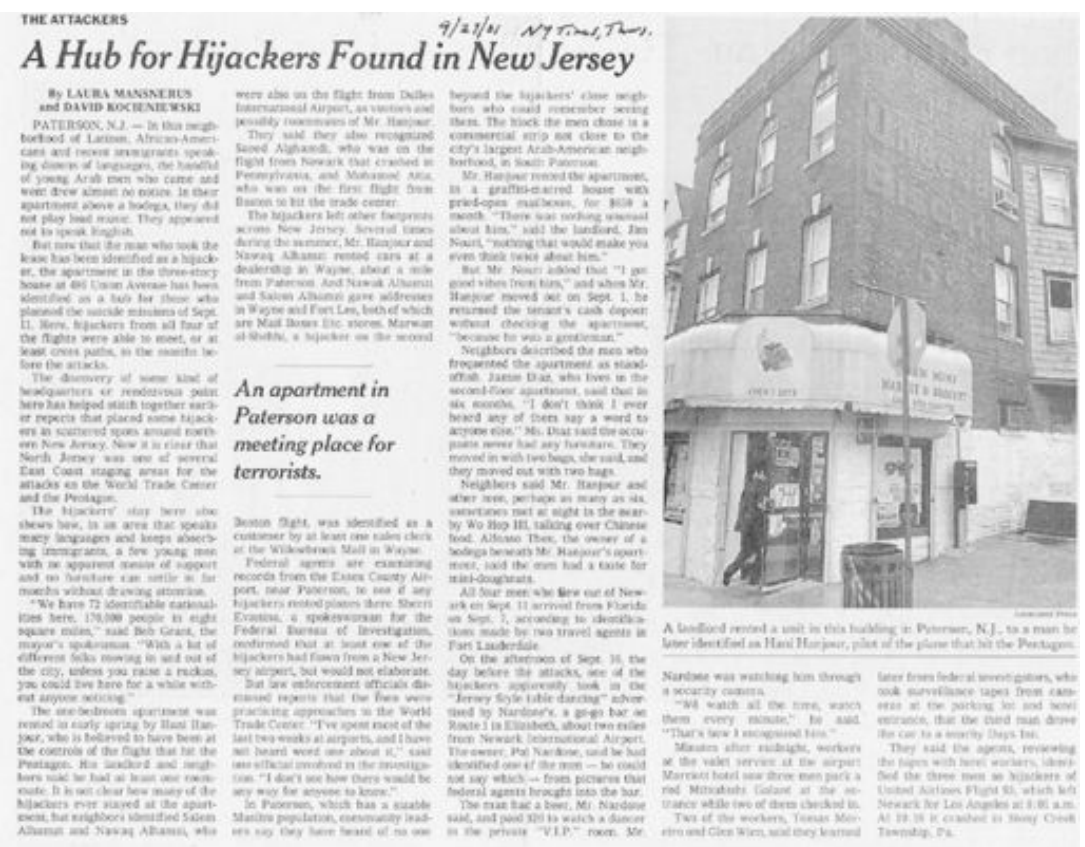

Even now Williams's Paterson continues its unforeseeable unfoldings, the city showing up in the news as a part of the terror of today. As such, the epic poem abruptly added a new feature to itself, perhaps an additional appendix, with Paterson described in the New York Times as a "hub for hijackers," those that brought down the World Trade Center and smashed into the Pentagon. One wonders what Williams would make of Paterson today, the poet's "selected" city that was later to be selected by the hijackers as a "headquarters," a "staging ground." So much of Williams's poem depended upon the written records found in the local library as he culled through old newspapers and civic documents, extracting printed artifacts of time's own testimony, its insistent dissolve. Today's papers now join that expanding site of time, the enlarging archive, offering further evidence of that unknowable city, that story with no end. 